Document downloaded from:

http://hdl.handle.net/10251/60347

This paper must be cited as:

Corbatón Báguena, MJ.; Gugliuzza, A.; Cassano, A.; Mazzei, R.; Giorno, L. (2015). Destabilization and removal of immobilized enzymes adsorbed onto polyethersulfone ultrafiltration membranes by salt solutions. Journal of Membrane Science. 486:207-214. doi:10.1016/j.memsci.2015.03.061.

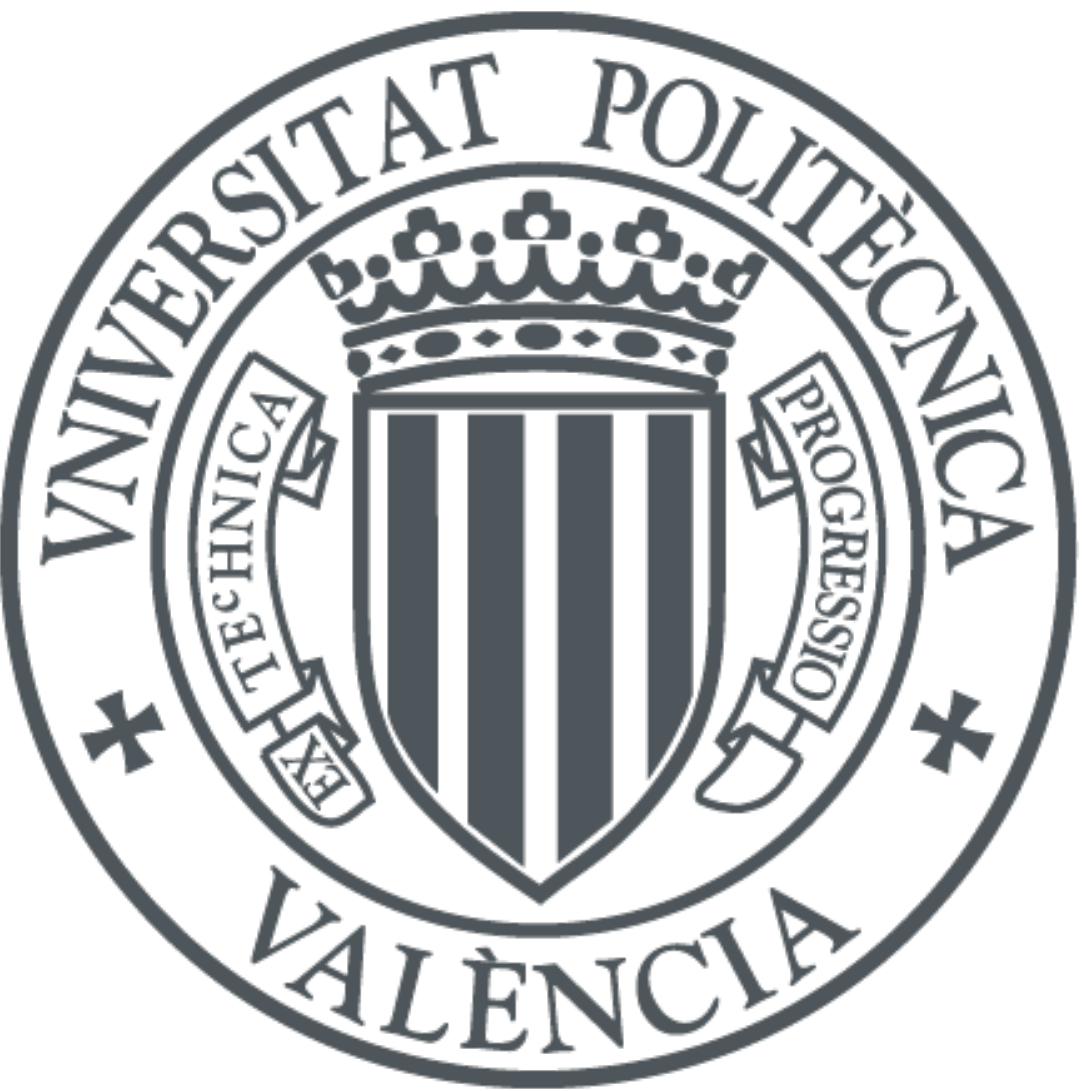

The final publication is available at

http://dx.doi.org/10.1016/j.memsci.2015.03.061

Copyright Elsevier

Additional Information 


\title{
Destabilization and removal of immobilized enzymes adsorbed onto polyethersulfone ultrafiltration membranes by salt solutions
}

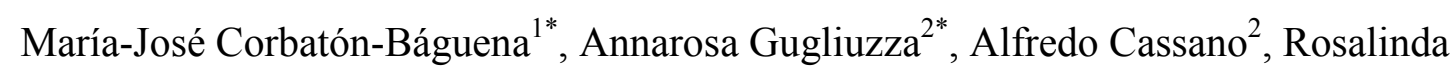
Mazzei $^{2}$, Lidietta Giorno ${ }^{2}$

${ }^{1}$ Department of Chemical and Nuclear Engineering, Universitat Politècnica de València, C/Camino de Vera s/n 46022 Valencia, Spain

${ }^{2}$ Institute on Membrane Technology, ITM-CNR, clo University of Calabria, via P. Bucci, 17/C, I-87030 Rende (Cosenza), Italy

*Corresponding author 1 :

María-José Corbatón-Báguena

$\mathrm{Ph}:+34963879633$

Fax : +34963877639

e-mail: macorba@upvnet.upv.es

*Corresponding author2:

Dr Annarosa Gugliuzza Ph.D.

$\mathrm{Ph}:+390984492026$ / 2004 / 2005

Fax : +390984 402103

e-mail: a.gugliuzza@itm.cnr.it

\begin{abstract}
In this work the effectiveness of two saline solutions $\left(\mathrm{NaCl}\right.$ and $\left.\mathrm{Na}_{2} \mathrm{SO}_{4}\right)$ to clean a permanently hydrophilic polyethersulfone (PESH) ultrafiltration (UF) membrane with a molecular weight cut-off (MWCO) of $30 \mathrm{kDa}$ previously fouled with enzymatic solutions
\end{abstract}


was investigated. The influence of protein concentration in the enzymatic solution during the fouling step and the effect of salt type during the cleaning procedure were studied.

The protein aggregation was analysed in solution and onto the membrane surface by using several techniques including Dynamic Light Scattering (DLS), Atomic Force Microscopy (AFM) and Infrared Spectroscopy with Attenuated Total Reflectance (ATR-FTIR). In addition, mechanisms that dominate membrane fouling were studied by fitting some mathematical models (Hermia's models adapted to crossflow filtration, a combined model based on the complete blocking and cake formation equations and a resistance-in-series model) to the experimental data.

Fouling results showed that the complete blocking/adsorption on membrane surface was the predominant fouling mechanism. Regarding the cleaning results, higher cleaning efficiency and low residual protein concentration was obtained with $\mathrm{NaCl}$ solutions for all the feed solutions tested due to the favourable interaction between $\mathrm{Cl}^{-}$and proteins.

Keywords: membrane cleaning; protein fouling; salt solutions; ultrafiltration; mathematical models

\section{Introduction}

Fouling due to protein-membrane interactions can influence and strongly limit the performance of membranes in several processes such as: proteins separation/fractionation, removal of denatured enzymes in biocatalytic membrane reactors and clarification of food streams.

It is well known that pectinases are enzymes largely used in fruit juice microfiltration (MF) or ultrafiltration (UF) in order to hydrolize pectic substances, i.e. complex glycosidic macromolecules with high molecular weight and negative charge [1] which are responsible 
for membrane fouling. In addition, pectinases can be also immobilized on different supports depending on the industrial application including fruit juice and olive mill wastewater processing $[2,3]$.

Enzyme immobilization techniques and membrane fouling mechanisms have similar characteristics, physical and/or interfacial donor/acceptor interactions being surface controlling factors [4-7]. In this way, Luo et al. [8] stated that enzymatic entrapment on membranes may be considered as a pore blocking mechanism and the adsorption fouling can be related to the enzymatic adsorption on the membrane surface due to hydrophobic and electrostatic interactions. In their work, fouling mechanisms that dominate the enzyme filtration were analyzed by two different mathematical models: a resistance-in-series model considering the intrinsic membrane resistance, the reversible fouling resulting from concentration polarization layer or particle deposit and the irreversible fouling including pore blocking or cake deposit and the classical Hermia's models applied to dead-end filtration. Other authors also used these models to investigate membrane fouling. VincentVela et al. [9] fitted the Hermia's models adapted to crossflow filtration to the experimental data obtained during the UF of polyethylenglycol. They concluded that the intermediate and complete blocking mechanisms were the models with the highest fitting accuracy for most of the operating conditions tested. De Barros et al. [10] identified the fouling mechanism as a function of the membrane material used during the crossflow UF of pineapple juice previously treated with enzymes. Results after fitting the Hermia's models adapted to crossflow showed that complete pore blocking and cake formation were the predominant mechanisms when using the ceramic and polymeric membranes, respectively. Similarly, Cassano et al. [11] established that the fouling mechanism involved in the crossflow UF of blood orange juice with a tubular polyvinylidenefluoride (PVDF) membrane evolved from a partial to a complete pore blocking in dependence of the axial 
feed velocity. Choi et al. [12] applied a resistance-in-series model to the MF of bovine serum albumin (BSA) taking into account the membrane resistance, the gel layer resistance and the fouling resistance due to the foulant deposits inside the membrane pores. They obtained good agreement with the experimental data recorded. Machado et al. [13] investigated the effect of an enzymatic treatment with pectin lyase of açaí pulp on its crossflow MF. They also studied the predominant fouling mechanisms by a resistance-inseries and the Hermia's models adapted to crossflow ones. They observed that fouling resistance decreased after the enzymatic treatment as well as the cake formation followed by intermediate and complete pore blocking mechanisms dominated the MF process. However, as Luo et al. described [8], during the immobilization of enzymes the convective transport of enzymes to the membrane surface makes these particles to be retained on it and thus, enzymes cause an increase in the local concentration. As a result, concentration polarization increases and a fouling layer can be formed on the membrane surface or inside its pores. In order to remove such a fouling layer, membranes have to be cleaned. Conventional cleaning protocols involve chemical cleaning agents such as alkalis, acids, disinfectants, surfactants or combinations of them [14]. However, these conventional cleaning methods may be aggressive for the membranes and their lifetime and selectivity may be reduced. In addition, these conventional cleaning agents cause a negative environmental impact when they are discharged as wastewaters after the cleaning step. For all these reasons, new alternative cleaning techniques, including ultrasounds [15], electromagnetic fields [16] and saline solutions [17] have been developed in the recent years to overcome these problems. Regarding the use of saline solutions, previous studies reported the salting-in and salting-out effect of different cations and anions to increase or decrease, respectively, protein solubility at $\mathrm{pH}$ values above and below the isoelectric point of the protein $[18,19]$. Lee et al. [17] also investigated the cleaning mechanism of saline 
solutions: in a first stage, the difference between the bulk solution concentration and the gel layer concentration on the membrane surface causes changes on the cross-linked fouling layer. Then, an ion-exchange reaction takes place between the ions forming the gel layer on the membrane surface and the salt ions of the cleaning solution that diffuse in the gel layer. This ion exchange results in a swelling and removal of the gel layer by freeing the protein molecules and favouring their transport to the bulk solution.

The aim of this work is to investigate the effectiveness of $\mathrm{NaCl}$ and $\mathrm{Na}_{2} \mathrm{SO}_{4}$ solutions for cleaning a PESH UF membrane with a molecular weight cut-off (MWCO) of $30 \mathrm{kDa}$ that was previously fouled with enzymatic solutions of pectinases at different protein concentration $(2,7.5$ and $15 \mathrm{~g} / \mathrm{L})$. The influence of protein concentration on membrane fouling was studied by AFM and ATR-FTIR techniques and the fouling mechanism that dominates the UF of each feed solution tested was also determined by fitting three mathematical models to the experimental data: Hermia's models adapted to crossflow filtration, a combined model based on the complete blocking and cake formation mechanisms and a resistance-in-series model. The membrane cleanliness was evaluated by ATR-FTIR measurements and the residual protein concentration adsorbed on the membrane surface was also quantified.

\section{Materials and methods}

\subsection{Chemicals}

Enzymatic solutions of pectinases (Pectinex Smash XXL, Novozymes) at different protein concentrations $(2,7.5$ and $15 \mathrm{~g} / \mathrm{L})$ were used as feed solutions during the fouling step. According to the manufacturer information, the enzymatic solution is mainly composed of pectin lyases from Aspergillus niger. $\mathrm{NaCl}$ and $\mathrm{Na}_{2} \mathrm{SO}_{4}$ solutions were the cleaning agents 
tested. Protein concentration in the enzymatic solutions was determined by the Bicinchoninic Acid (BCA) assay (Sigma Aldrich).

\subsection{Experimental set-up}

A permanently hydrophilic polyethersulfone (PESH) ultrafiltration membrane (Microdyn Nadir, Germany) with a MWCO of $30 \mathrm{kDa}$ was tested in the experiments. The main characteristics of the virgin membrane are shown in Table 1.

All the fouling and cleaning experiments were performed in a conventional crossflow UF system. It consisted of a feed tank of $1 \mathrm{~L}$, a variable speed pump, a stainless-steel cell able to accommodate a flat-sheet membrane and a permeate tank. Transmembrane pressure was measured by two manometers allocated before and after the membrane module and regulated by a pressure control valve located on the retentate line. Crossflow velocity was controlled by a digital flowmeter. Temperature was set at $25 \pm 1{ }^{\circ} \mathrm{C}$ during the fouling and rinsing steps using a cooling system fed with tap water, while during the cleaning step temperature was set at $50 \pm 3^{\circ} \mathrm{C}$ using a heater.

\subsection{Experimental procedure}

Fouling tests were carried out with an enzymatic solution at three different protein concentrations $(2,7.5$ and $15 \mathrm{~g} / \mathrm{L})$ without $\mathrm{pH}$ adjustment ( $\mathrm{pH}$ value of about 4.3). Experimental conditions of transmembrane pressure, crossflow velocity and temperature were set at 2 bar, $2 \mathrm{~m} / \mathrm{s}$ and $25^{\circ} \mathrm{C}$, respectively. The duration of the fouling tests was $2 \mathrm{~h}$. These conditions were selected according to previous studies on protein solutions ultrafiltration [20-22].

After the fouling step, a first rinsing with distilled water was performed during $30 \mathrm{~min}$ at a transmembrane pressure of 1 bar and a crossflow velocity of $2.18 \mathrm{~m} / \mathrm{s}$. According to the 
literature [23], low transmembrane pressures and high crossflow velocities favour the removal of solute molecules deposited on the membrane surface. Then, a cleaning step with saline solutions during $60 \mathrm{~min}$ and a second rinsing step with distilled water during 30 min were carried out at the same experimental conditions of transmembrane pressure as the first rinsing step. $\mathrm{NaCl}$ and $\mathrm{Na}_{2} \mathrm{SO}_{4}$ solutions were tested during the cleaning protocol at a concentration of $5 \mathrm{mM}$ and a temperature of $50^{\circ} \mathrm{C}$. These conditions were the optimal ones in previous studies about saline cleaning of membranes fouled with protein solutions [20, 21].

Permeate flux and hydraulic resistance were monitored during all the steps of the experimental procedure. Once the cleaning procedure was finished, water permeability was measured again in order to evaluate the cleaning efficiency, expressed as:

$$
C E=\frac{W P_{1}}{W P_{0}} \cdot 100
$$

where $W P_{1}$ and $W P_{0}$ are the water permeability of the cleaned and virgin membrane, respectively.

\subsection{Characterization of the enzymatic solutions}

The BCA assay was used to determine the protein concentration in the enzymatic solutions $[24,25]$. This assay is a colorimetric method based on the formation of $\mathrm{a} \mathrm{Cu}^{+2}$-protein complex under alkaline conditions. Then, reduction of $\mathrm{Cu}^{+2}$ to $\mathrm{Cu}^{+1}$ takes place and the amount of reduction is directly proportional to the amount of protein in the sample. According to the standard assay protocol, $0.1 \mathrm{~mL}$ of sample were mixed with $2 \mathrm{~mL}$ of the BCA working reagent and incubated at $37^{\circ} \mathrm{C}$ during $30 \mathrm{~min}$. Then, samples were cooled at room temperature and absorbance was measured at a wavelength of $562 \mathrm{~nm}$ by a UVvisible spectrophotometer. By using a calibration test performed with the bovine serum 
albumin (BSA) standard solution, protein concentration in the enzymatic solutions was estimated. Each sample was duplicated for the measurement.

Size measurements of protein particles were carried out by Zetasizer nano (Malvern Instruments). The Zetasizer system determines the particles size by measuring the Brownian motion of the particles in a sample using Dynamic Light Scattering (DLS). Previous studies demonstrated that these techniques were suitable for protein characterization $[26,27]$. In order to analyse the particle size in pectinase solution in the conditions in which membrane was fouled with pectinase (at $25^{\circ} \mathrm{C}$ ) and during cleaning treatment (at $50{ }^{\circ} \mathrm{C}$ in presence of $\mathrm{NaCl}$ ), different analysis were carried out by DLS varying protein concentration $(2,7,15 \mathrm{~g} / \mathrm{L})$. In addition protein size measurements at 15 $\mathrm{g} / \mathrm{L}$ were also carried out in presence of $\mathrm{NaCl}(5 \mathrm{mM})$. Hypothesis testing considering a confidence interval of $95 \%$ and using the Statgraphics ${ }^{\circledR}$ Centurion XVI software were performed in order to determine if statistically significant differences exist among the particle size distributions at $25^{\circ} \mathrm{C}, 50{ }^{\circ} \mathrm{C}$ and the combination of $50{ }^{\circ} \mathrm{C}$ and $\mathrm{NaCl}$ [28].

\subsection{Membrane characterization}

Prior to the fouling experiments, the membrane was compacted with ultrapure water by increasing and decreasing the transmembrane pressure from 1 bar to 4 bar until a constant hydraulic permeability was obtained. Accordingly, the intrinsic membrane resistance $\left(\mathrm{R}_{\mathrm{m}}\right)$ was calculated. Ultrapure water was used in order to prevent additional dirty on the membrane surface.

Infrared spectra in ATR mode were collected onto the membrane surface before and after each fouling and cleaning experiments by using an ATR-FTIR spectrometer (Spectrum One, Perkin Elmer). The adsorption and deposition of proteins on the membrane surface and related changes in the surface roughness were detected by using Atomic Force 
Microscopy (AFM), Nanoscope III (Digital Instruments, VEECO Metrology Group). Tapping Mode AFM operated by scanning a tip attached to the end of an oscillating cantilever across $2.5 \times 2.5 \mu \mathrm{m}$ of sample surface.

The amount of residual material adsorbed onto the membrane surface was quantified according to the following equation [29]:

$$
\frac{H_{1539}}{H_{1240}}=0.0034 \cdot C_{\text {protein }}+0.0165 \quad \text { Eq.2 }
$$

where $H_{1539}$ is the height of the absorption band at $1539 \mathrm{~cm}^{-1}$ (amide 2), $H_{1240}$ is the height of the absorption band at $1240 \mathrm{~cm}^{-1}$ (PES membrane) and $C_{\text {protein }}$ is the residual protein concentration deposited on membrane surface. This equation is valid in the protein concentration range of $0.5-350 \mu \mathrm{g} / \mathrm{cm}^{2}$ with a maximum deviation of $1 \mu \mathrm{g} / \mathrm{cm}^{2}$, according to [30].

\subsection{Mathematical modelling}

Different mathematical models were fitted to the experimental data obtained during the UF of pectinase solutions using the MathCad ${ }^{\circledR}$ Genfit algorithm, which minimizes the overall difference between experimental and predicted results by the Levenberg-Marquadt method. The success of fitting was evaluated in terms of regression coefficient $\mathrm{R}^{2}$ and standard deviation SD.

\subsubsection{Hermia’s models}

Hermia [31] developed four models based on classical constant pressure dead-end filtration equations in order to describe four main types of membrane fouling: complete blocking, intermediate blocking, standard blocking and cake layer formation. Several authors [9-11, 32] adapted these models to crossflow configuration by incorporating the flux associated 
with the back-transport mass transfer, which is evaluated at the steady-state [33]. Eq. 3 shows the general equation for Hermia's models adapted to crossflow UF:

$$
-\frac{d J}{d t}=K\left(J-J_{s S}\right) J^{2-n} \quad \text { Eq. } 3
$$

where $J$ is the permeate flux, $K$ is a model constant, $\mathrm{n}$ is the model parameter and $J_{s s}$ is the permeate flux when the steady-state is achieved.

Four different models corresponding to the four fouling mechanisms above mentioned are considered depending on the value of the parameter $n$ : complete blocking $(n=2)$, intermediate blocking $(n=1)$, standard blocking $(n=1.5)$ and gel layer formation $(n=0)$. Complete blocking model takes into account that a solute molecule that reaches to membrane surface blocks a pore entrance completely without penetrating inside the pores. This model assumes that a monomolecular layer is formed on the membrane surface.

The intermediate blocking model considers that a solute molecule can deposit on previously settled ones. However, as in the complete blocking model, fouling takes place only on the membrane surface.

When solute molecules are smaller than membrane pore size, these molecules can penetrate inside the pores. This is the main hypothesis of the standard blocking model.

Cake formation model is based on the assumption that solute molecules accumulate on membrane surface because they have a larger size than membrane pores. Therefore, a permeable layer is formed on the membrane surface.

\subsubsection{Combined model}

Previous studies [32-35] reported that the typical variation of permeate flux with time includes two fouling mechanisms: a rapid flux decline during the first minutes of operation due to pore blocking and an accumulation of foulants on the membrane surface that causes a long term flux decline due to a cake formation. In this work, a combined model 
considering the Hermia's equations for crossflow UF corresponding to complete blocking and cake formation was used to predict the permeate flux decline. Therefore, the general equation of the combined model is Eq. 4, where $\alpha$ is the fraction of membrane pores that are completely blocked:

$$
J_{\text {combined model }}=\alpha J_{\text {complete blocking model }}+(1-\alpha) J_{\text {cake formation model }} \text { Eq. } 4
$$

Eq. 4 involves two different constants depending on the fouling mechanism: $\mathrm{K}_{\mathrm{c}}$ for the complete blocking model and $K_{c f}$ for the cake formation model. The parameter $K_{c}$ corresponds to the blocked membrane surface per unit of total permeate volume and unit of membrane surface porosity. On the other hand, $K_{c f}$ represents the ratio between the cake characteristics (specific cake resistance and cake mass per unit of total permeate volume) and the original membrane ones [9].

\subsubsection{Resistance-in-series model}

According to the Darcy's law (Eq. 5), permeate flux is related to the transmembrane pressure and the total hydraulic resistance:

$$
J=\frac{\Delta P}{\mu \cdot R}
$$

where $\Delta P$ is the transmembrane pressure, $\mu$ is the feed solution viscosity and $R$ is the total hydraulic resistance.

In the resistance-in-series model, the total hydraulic resistance is the sum of different resistances that contribute to the permeate flux decline during the UF process. In this work, the membrane resistance, the cake resistance and the adsorption and concentration polarization resistances were considered (Eq. 6):

$$
J=\frac{\Delta P}{\mu \cdot\left(R_{m}+R_{a d}+R_{c}\right)} \quad \text { Eq. } 6
$$


where $R_{m}$ is the virgin membrane resistance, $R_{c}$ is the cake resistance and $R_{a d}$ is the resistance due to adsorption on/in membrane surface and pores and concentration polarization. In addition, $R_{a d}$ can be expressed as an exponential function of the steadystate adsorption and concentration polarization resistance and the rate at which foulant molecules are deposited on the membrane $[12,36]$. Therefore, Eq. 7 shows the general equation for the resistance-in-series model:

$$
J=\frac{\Delta P}{\mu \cdot\left(R_{m}+R_{a d}^{\prime}(1-\exp (-b t))+R_{c}\right)}
$$

where $R^{\prime}{ }_{a d}$ is the steady-state adsorption and concentration polarization resistance and $b$ is the fouling rate due to adsorption.

\section{Results and discussion}

\subsection{Fouling results}

\subsubsection{Determination of protein fouling}

DLS measurements on protein solutions (Table 2) showed a bimodal distribution for all the protein concentrations tested at $25{ }^{\circ} \mathrm{C}$. As it is possible to observe, the particle size belonging to distribution 2 increased as a function of concentration, reaching a value of $410 \pm 221 \mathrm{~nm}$ at $15 \mathrm{~g} / \mathrm{L}$. The increase in size, as well as the high PDI, suggested a severe protein aggregation which is expected to lead to a higher fouling during the UF process when the protein concentration is increased.

AFM and ATR-FTIR measurements also demonstrated that protein fouling increased with the protein concentration in the enzymatic solution, causing a general increase in the surface roughness as well. Fig. 1 shows the $2 \mathrm{D}$ AFM images of the virgin and fouled membranes at different protein concentration (2, 7.5 and $15 \mathrm{~g} / \mathrm{L})$. When protein concentration was $2 \mathrm{~g} / \mathrm{L}$ big protein aggregates can be well distinguished from membrane surface while the membrane surface continues to exhibit the same surface morphology of 
the initial one, causing a dramatic increase in the surface roughness with value of $R_{a}$ of $28 \pm 8 \mathrm{~nm}$ (Fig. 1b). At $7.5 \mathrm{~g} / \mathrm{L}$ the layer is partially formed on the membrane surface, revealing heterogeneous regions where initial membrane structure and isolated protein aggregates are well distinguished (Fig. 1c). In comparison with previous situation ( $2 \mathrm{~g} / \mathrm{L})$ the protein clusters decrease in size but increase in number. At the highest concentration tested, a gel layer that completely covers the original membrane surface can be observed, producing an increase in surface roughness (Fig. 1d) as compared with the virgin membrane. On this basis it can be assumed that protein-membrane interaction, as well as protein cluster disassembling, is favoured when protein concentration is raised. On the other hand, it is relevant to underline that the convective transport to the membrane enhances protein overlapping with gel formation. These results are in agreement with those obtained by Ohnishi et al. [37], who demonstrated protein layer was denser at the highest concentration tested, as it occurs in our work.

ATR-FTIR spectra were collected onto virgin and fouled membranes. An intense absorption band can be detected at about $1650 \mathrm{~cm}^{-1}$ due to the stretching vibration of $\mathrm{C}=\mathrm{O}_{\text {amide }}$ typical of the amide I group (Fig. 2a). This band becomes more intense for membranes fouled with solutions at $2 \mathrm{~g} / \mathrm{L}$. The broadness of this band along with the appearance of a strong IR mode at $1504 \mathrm{~cm}^{-1}$, which is typical of a $\mathrm{C}-\mathrm{H}_{\text {arom }}$ bond, suggests a strong contribution of the aromatic component to the spectrum due to different rearrangement of the protein aggregates when binding the membrane surface. Also, at 1168 $\mathrm{cm}^{-1}$ an IR mode associated to C-O-C stretching vibrations appears to be more intense confirming a different local chemical environment due to a varied rearrangement of the protein assembling. It is noteworthy that stretching located at 1620 towards higher frequency suggests intermolecular $\beta$-sheets bonds confirming a protein aggregation state $[38,39]$. 
Another diagnostic weak band is observed at around $1730 \mathrm{~cm}^{-1}$, which corresponds to $\mathrm{C}=\mathrm{O}_{\text {ester }}$ bond. This infrared mode was detected in the spectra for all the fouled membranes with the same band intensity, whereas it was never observed in the new membrane spectrum. It is relevant to underline that the strong IR absorption bands, which characterize the spectrum of fouled membranes with $2.0 \mathrm{~g} / \mathrm{L}$, are due to local adsorption of protein aggregates completely spanned at higher concentration as confirmed by AFM images (Figs. 1b,d).

\subsubsection{Mathematical modelling}

The mean value of the intrinsic membrane resistance $\left(\mathrm{R}_{\mathrm{m}}\right)$ was $3.8 \cdot 10^{12} \mathrm{~m}^{-1}$. This value was taken as a constant in the resistance-in-series model.

Fig. 3 shows the time evolution of the experimental permeate flux obtained for all the feed solutions tested. As expected, a lower permeate flux was measured by increasing the protein concentration due to a more severe membrane fouling. This is in accordance with the AFM image (Fig. 1d) where all the membrane pores appear to be fully covered by a protein layer. Fig. 3 also shows the permeate flux predictions by the two models with the highest fitting accuracy (highest regression coefficient, $\mathrm{R}^{2}$, and lowest standard deviation, SD). In all cases, resistance-in-series and the combined model were the models with the best fitting accuracy for all the feed solutions tested, with values of $\mathrm{R}^{2}$ ranging from 0.91 to 0.99 and SD values from 0.01 to 0.04 , while the accuracy of Hermia's models varied from 0.85 to 0.96 for $\mathrm{R}^{2}$ values and from 0.03 to 0.06 for $\mathrm{SD}$. Both resistance-in-series and combined models considered that complete blocking/adsorption and cake formation were the main mechanisms contributing to membrane fouling. Therefore, both mechanisms should be considered to explain the membrane fouling with enzymatic solutions at the experimental conditions tested ( 2 bar, $2 \mathrm{~m} / \mathrm{s}$ and $25^{\circ} \mathrm{C}$ ). 
Table 3 shows the values of model parameters for the best fitting models. The values of the parameters $\mathrm{R}_{\text {ad }}, \mathrm{R}_{\mathrm{c}}, \mathrm{K}_{\mathrm{c}}, \mathrm{K}_{\mathrm{cf}}$ and $\alpha$ increased when protein concentration increased. This is due to the fact that more severe membrane fouling occurs with increasing protein concentration in the feed solutions. A similar behaviour was observed in the MF process of BSA solutions [35].

Regarding the value of the parameter $\alpha$, which indicates the fraction of completely blocked pores (Eq. 4), the predominant fouling mechanism was complete blocking for all the feed solutions tested. This is in agreement with the particle size measured: the largest size of pectinase molecules $(50 \mathrm{kDa})$ compared to the membrane MWCO (30 kDa) allows these particles to be deposited on the membrane surface blocking the pore entrance. On the other hand, concentration polarization increased when protein concentration increased [33] and thus, the value of the resistance $\mathrm{R}_{\text {ad }}$ that considers both adsorption and concentration polarization phenomena at steady-state, was the highest at $15 \mathrm{~g} / \mathrm{L}$. In addition, as displayed in AFM images (Fig. 1d), at the highest concentration tested, the cake formed on the membrane surface was denser. This resulted in the increased parameters related to the cake formation, $R_{c}$ and $K_{c f}$. Regarding the intermediate pectinase concentration $(7.5 \mathrm{~g} / \mathrm{L})$, the values of all these parameters also increased from those obtained at $2 \mathrm{~g} / \mathrm{L}$, due to the partial formation of the protein layer on the membrane surface (Fig. 1c). However, the values of the model parameters were much lower than those obtained at $15 \mathrm{~g} / \mathrm{L}$, as there were initial membrane regions uncovered at the intermediate protein concentration. However, the same pattern was not observed for the parameter $b$, which represents the rate at which foulant molecules are adsorbed on membrane surface. In this case, when protein concentration increased, the value of $b$ decreased. As the ATR-FTIR spectra of the fouled membranes indicated, at the lowest concentration used ( $2 \mathrm{~g} / \mathrm{L})$, the protein-membrane interaction became greater due to the low amount of proteins compared to that when working at 15 
$\mathrm{g} / \mathrm{L}$. As a consequence, proteins were deposited on membrane surface at a higher rate than in the case of high protein concentration.

\subsection{Membrane cleaning}

Fig. $2 b$ shows the spectra of the virgin and the cleaned membranes that were fouled with enzymatic solutions at protein concentrations of 2, 7.5 and $15 \mathrm{~g} / \mathrm{L}$. As it can be observed, an almost total overlapping among all the spectra was obtained, which is an indicator of the removal of protein deposits on the membrane surface using $\mathrm{NaCl}$ as cleaning agent at a concentration of $5 \mathrm{mM}$ and $50{ }^{\circ} \mathrm{C}$. The only exceptions are the appearance of a band at a frequency of $1750 \mathrm{~cm}^{-1}$, which can be attributed to ester carbonyl and a band at a frequency of $1040 \mathrm{~cm}^{-1}$, which can be related to the C-N stretching vibrations typical of proteins [40]. The band intensity is somewhat significant on fouled membranes (Fig. 2a) whereas it remained becomes negligible after the cleaning procedure (Fig. 2b). This provides indications about the efficiency of the cleaning procedures, the presence of some residual contaminants being onto the membrane surface.

Table 4 shows the results of residual protein concentration adsorbed on membranes and of the cleaning efficiency. Regarding the values of protein concentration after $\mathrm{NaCl}$ cleaning, it can be observed that all membranes showed a low amount of proteins on their surface, even if a gradual increase in the residual adsorption was detected for membranes fouled at higher protein concentration. Indeed the deposition of larger amount of protein at higher concentration was also revealed by AFM analyses. These results are in good agreement with those obtained by Rabiller-Baudry et al. [30] which studied the efficiency of several cleaning agents for PES UF membranes fouled with skim milk. In this case the best

cleaning agents led to a residual protein concentration from 3 to $11 \mu \mathrm{g} / \mathrm{cm}^{2}$ at a transmembrane pressure of 1 bar. On the other hand, according to the cleaning efficiency 
evaluation (Table 4), it can be concluded that the low protein amount deposited on the membrane surface for the different protein concentrations tested did not greatly affect the membrane permeation properties.

The effect of salt type on the cleaning efficiency was also studied by means of ATR-FTIR measurements. Fig. 2c shows the spectra of the virgin and cleaned membranes, previously fouled with a $15 \mathrm{~g} / \mathrm{L}$ protein concentration, by using $\mathrm{NaCl}$ and $\mathrm{Na}_{2} \mathrm{SO}_{4}$ solutions. It is relevant to observe the appearance of two bands at $1504 \mathrm{~cm}^{-1}$ and $1168 \mathrm{~cm}^{-1}$ in the spectrum associated to membranes cleaned with $\mathrm{Na}_{2} \mathrm{SO}_{4}$ (Fig. 2c). This suggests the presence of residual proteins not completely removed by the cleaning procedure. As previously described, these two bands indicate a different protein rearrangement on the membrane surface at lower protein concentration. Indeed, the spectrum is comparable to that recorded onto membranes fouled with $2 \mathrm{~g} / \mathrm{L}$ pectinase (Fig. 2a). In addition, the shift of the infrared mode located around $1620 \mathrm{~cm}^{-1}$ towards higher frequency suggests a contribution of the band usually assigned to intermolecular $\beta$-sheets bonds, well known as "aggregation band" [38, 39]. This shift is also observable for membranes coming in contact with $2 \mathrm{~g} / \mathrm{L}$ pectinase solution (Fig. 2a).

The residual protein concentration quantified from the ATR-FTIR spectrum was calculated for the $\mathrm{Na}_{2} \mathrm{SO}_{4}$ cleaning protocol (Table 4). In this table, the greatest amount of protein deposited on the membrane surface after cleaning procedure was obtained with $\mathrm{Na}_{2} \mathrm{SO}_{4}$ $\left(24.68 \mu \mathrm{g} / \mathrm{cm}^{2}\right)$ and the cleaning efficiency was slightly lower than those obtained when $\mathrm{NaCl}$ was used as cleaning agent.

The different cleaning efficiency obtained with the two salt solutions can be ascribed to salting-in and salting-out mechanisms. $\mathrm{Na}_{2} \mathrm{SO}_{4}$ showed a strong salting-out effect and enhanced protein aggregation and adsorption according to Tsumoto et al. [41]. In addition, $\mathrm{SO}_{4}{ }^{2-}$ exhibits a salting-out effect higher than $\mathrm{Cl}^{-}$, causing a protein precipitation. This is 
due to the different ability of anions to interact with water molecules [18]. According to the law of matching water affinities, monovalents anions $\left(\right.$ as $\left.\mathrm{Cl}^{-}\right)$are weakly hydrated because they have a larger size than monovalent cations and they preferably interact with the positive-charged side chains of proteins and with the non-polar functional groups that are weakly hydrated as well [19]. This behaviour was also observed in a previous study about salt cleaning of membranes fouled with whey model solutions [21], in which similar efficiencies to those reported in Table 4 after the cleaning procedure were achieved.

On the basis of these experimental findings, DLS analyses were also performed in order to evaluate the combined effect of $\mathrm{NaCl}$ and temperature on protein aggregates destabilization/solubilisation. As it can be observed in Table 2, membrane cleaning with $\mathrm{NaCl}$ at $50{ }^{\circ} \mathrm{C}$ led to an additional protein aggregates destabilization that enhances saltingin effects. In particular, when the temperature was increased from $25^{\circ} \mathrm{C}$ to $50{ }^{\circ} \mathrm{C}$, with and without $\mathrm{NaCl}$, the changes in size observed for the particles belonging to both the first and second distribution were statistically significant (p-values lower than 0.05 ), while a big effect of particle decrease is observed for the distribution 2. This effect demonstrated that the distribution 2 is characterized by big aggregates that, thanks to a temperature effect, are destabilized. In addition, for what concerns particles belonging to distribution 1, any substantial change is observed both increasing temperature and in presence of $\mathrm{NaCl}$ $(5 \mathrm{mM})$, but a greater change in size is observed for particles belonging to distribution 2 . In this last case, the combination of $\mathrm{NaCl}$ and temperature $\left(50{ }^{\circ} \mathrm{C}\right)$ resulted in a decrease in particle size from 288 to $240 \mathrm{~nm}$. At higher temperature protein hydration is favoured. This means that protein-water bonds are predominant, causing solubilisation of protein aggregates. In the presence of $\mathrm{NaCl}$, protein-protein interactions are further broken due to salting-in effects, thus promoting higher hydration shell $[41,42]$. 


\section{Conclusions}

Fouling experiments performed with enzymatic solutions of pectinases at different protein concentrations $(2,7.5$ and $15 \mathrm{~g} / \mathrm{L})$ demonstrated that a higher protein concentration caused a more severe UF membrane fouling. AFM images as well as ATR measurements carried out on the virgin and fouled membranes confirmed that a continuous protein layer was formed on the membrane surface when a concentration of $15 \mathrm{~g} / \mathrm{L}$ was used.

The mathematical models studied in this work predicted with high accuracy the experimental permeate flux decline corresponding to the UF of enzymatic solutions of pectinases at different protein concentration $(2,7.5$ and $15 \mathrm{~g} / \mathrm{L}), 2$ bar and $2 \mathrm{~m} / \mathrm{s}$. The Hermia's standard blocking model did not fit well the experimental data since the solute molecules size was larger than the membrane pore size and thus, these molecules cannot penetrate inside the membrane pores. Adversely, the models that showed the best fitting accuracy were the combined model and the resistance-in-series, one of which suggested a predominant pore blocking/adsorption mechanism, followed by a cake formation.

Among the salts tested, $\mathrm{NaCl}$ showed better results than $\mathrm{Na}_{2} \mathrm{SO}_{4}$ due to a better ability to dissolve proteins from membrane surface for salting-in effect. The cleaning efficiency of $\mathrm{NaCl}$ in combination with temperature was also investigated by DLS experiments, thus confirming a cooperation of the two parameters in the protein aggregates destabilization. The cleaning efficiency was investigated through water permeability measurements. Although some residual contaminants were still present after cleaning with $\mathrm{NaCl}$ solution, the initial permeability value was completely restored. The suitability and reliability of the cleaning procedure with $\mathrm{NaCl}$ was confirmed with other protein solutions (whey model solutions), achieving similar cleaning efficiencies. 


\section{Acknowledgements}

María-José Corbatón-Báguena wishes to gratefully acknowledge the financial support from the Spanish Ministry of Economy and Competitiveness through the grant EEBB-I-1409011 (project CTM2010-20186). The authors acknowledge the European Union, Fondo Europeo di Sviluppo Regionale, The Ministero dell'Istruzione, dell'Università e della Ricerca - MIUR, The Ministero dello Svilupppo Economico - MSE - for the financial support to the project "Sistemi tecnologici avanzati e processi integrati della filiera olivicola per la valorizzazione dei prodotti e dei sottoprodotti, lo sviluppo di nuovi settori e la creazione di sistemi produttivi Eco-compatibili” (PON Olio Più, PON01_01545), within the framework PON Ricerca e Competitività 2007-2013.

\section{References}

[1] R.S. Jayani, S. Saxena, R. Gupta, Microbial pectinolytic enzymes: A review, Process Biochem. 40 (2005) 2931-2944.

[2] H.L. Ramírez, A.I. Briones, J. Úbeda, M. Arévalo, Immobilization of pectinase by adsorption on an alginate-coated chitin support, Biotecnología Aplicada 30 (2013) 101104.

[3] A.Y. Gebreyohanees, R. Mazzei, E. Curcio, T. Poerio, E. Drioli, L. Giorno, Study on the in situ enzymatic self-cleansing of microfiltration membrane for valorization of olive mill wastewater, Ind. Eng. Chem. Res. 52 (2013) 10396-10405.

[4] R. Mazzei, E. Drioli, L. Giorno, Biocatalytic Membranes and Membrane Bioreactors, in: E. Drioli, L. Giorno (Eds.), Comprehensive Membrane Science and Engineering, Academic Press, Oxford, 2010, pp. 195-212. 
[5] L. De Bartolo, A. Gugliuzza, S. Morelli, B. Cirillo, A. Gordano, E. Drioli, Novel PEEK-WC membranes with low plasma protein affinity related to surface free energy parameters, J. Mater. Sci.: Mater. in Medicine 15 (2004) 877-883

[6] L. Yua, Y. Kan, M. Rapp, E. Danner, W. Wei, S. Das, D. R. Miller, Y. Chen, J. H. Waite, J. N. Israelachvili, Adaptive hydrophobic and hydrophilic interactions of mussel foot proteins with organic thin films, Proc. Natl. Acad. Sci. U.S.A. 110 (2013) 1568015685.

[7] G. De Luca, A. Gugliuzza, E. Drioli, Competitive hydrogen-bonding interactions in modified polymer membranes: A density functional theory investigation, J. Phys. Chem. B 113 (2009) 5473-5477.

[8] J. Luo, A.S. Meyer, G. Jonsson, M. Pinelo, Fouling-induced enzyme immobilization for membrane reactors, Biores. Technol. 147 (2013) 260-268.

[9] M.C. Vincent-Vela, S. Álvarez-Blanco, J. Lora-García, E. Bergantiños-Rodríguez, Analysis of membrane pore blocking models adapted to crossflow ultrafiltration in the ultrafiltration of PEG, Chem. Eng. J. 149 (2009) 232-241.

[10] S.T.D. de Barros, C.M.G. Andrade, E.S. Mendes, L. Peres, Study of fouling mechanism in pineapple juice clarification by ultrafiltration, J. Membr. Sci. 215 (2003) 213-224.

[11] A. Cassano, M. Marchio, E. Drioli, Clarification of blood orange juice by ultrafiltration: analyses of operating parameters, membrane fouling and juice quality, Desalination 212 (2007) 15-27.

[12] S-W. Choi, J-Y. Yoon, S. Haam, J-K. Jung, J-H. Kim, W-S. Kim, Modeling of the permeate flux during microfiltration of BSA-adsorbed microspheres in a stirred cell, J. Colloid Interface Sci. 228 (2000) 270-278. 
[13] R.M.D. Machado, R.N. Haneda, B.P. Trevisan, S.R. Fontes, Effect of enzymatic treatment on the cross-flow microfiltration of açaí pulp: Analysis of the fouling and recovery of phytochemicals, J. Food Eng. 113 (2012) 442-452.

[14] O.O. Ogunbiyi, N.J. Miles, N. Hilal, The effects of performance and cleaning cycles of new tubular ceramic microfiltration membrane fouled with a model yeast suspension, Desalination 220 (2008) 273-289.

[15] S. Muthukumaran, K. Yang, A. Seuren, S. Kentish, M. Ashokkumar, G.W. Stevens, R. Grieser, The use of ultrasonic cleaning for ultrafiltration membranes in the dairy industry, Sep. Purif. Technol. 39 (2004) 99-107.

[16] C.C. Tarazaga, M.E. Campderrós, A. Pérez Padilla, Physical cleaning by means of electric field in the ultrafiltration of a biological solution, J. Membr. Sci. 278 (2006) 219224.

[17] S. Lee, M. Elimelech, Salt cleaning of organic-fouled reverse osmosis membranes, Water Res. 41 (2007) 1134-1142.

[18] R.A. Curtis, L. Lue, A molecular approach to bioseparations: protein-protein and protein-salt interactions, Chem. Eng. Sci. 61 (2006) 907-923.

[19] J. Zhang, Protein-protein interactions in salt solutions, in: W. Cai, H. Hong (Eds.), Protein-Protein Interactions - Computational and Experimental Tools, InTech, Rijeka, 2012, pp. 359-376.

[20] M-J. Corbatón-Báguena, S. Álvarez-Blanco, M-C. Vincent-Vela, Cleaning of ultrafiltration membranesfouled with BSA by means of saline solutions, Sep. Purif. Technol. 125 (2014) 1-10.

[21] M-J. Corbatón-Báguena, S. Álvarez-Blanco, M-C. Vincent-Vela, Salt cleaning of ultrafiltration membranes fouled by whey model solutions, Sep. Purif. Technol. 132 (2014) 226-233. 
[22] P. Matzinos, R. Álvarez, Effect of ionic strength on rinsing and alkaline cleaning of ultrafiltration inorganic membranes fouled with whey proteins, J. Membr. Sci. 208 (2002) 23-30.

[23] P. Blanpain-Avet, J.F. Migdal, T. Bénézech, Chemical cleaning of a tubular ceramic microfiltration membrane fouled with a whey protein concentrate suspension characterization of hydraulic and chemical cleanliness, J. Membr. Sci. 337 (2009) 153-174.

[24] R.E. Morton, T.A. Evans, Modification of the bicinchoninic acid protein assay to eliminate lipid interference in determining lipoprotein protein content, Anal. Biochem. 204 (1992) 332-334.

[25] R.C. Krieg, Y. Dong, K. Schwamborn, R. Knuechel, Protein quantification and its tolerance for different interfering reagents using the BCA-method with regard to 2D SDS PAGE, J. Biochem. Biophys. Methods 65 (2005) 13-19.

[26] K.W. Mattison, M. Kaszuba, Automated protein characterization, Am. Biotechnol. Lab., 22 (2004) 8-11.

[27] N. Schultz, G. Metreveli, M. Franzreb, F.H. Frimmel, C. Syldatk, Zeta potential measurement as a diagnostic tool in enzyme immobilisation, Colloids Surf. B: Biointerfaces 66 (2008) 39-44.

[28] A.A. Alcheikhhamdon, N.A. Darwish, N. Hilal, Statistical analysis of air-gap membrane desalination experimental data: Hypothesis testing, Desalination 362 (2015) 117-125.

[29] M. Rabiller-Baudry, L. Bégoin, D. Delaunay, L. Paugam, B. Chaufer, A dual approach of membrane cleaning based on physico-chemistry and hydrodynamics. Application to PES membrane of dairy industry, Chem. Eng. Process. 47 (2008) 267-275. [30] M. Rabiller-Baudry, F. Gouttefangeas, J. Le Lannic, P. Rabiller, Coupling of SEMEDX and FTIR-ATR to (quantitatively) investigate organic fouling on porous organic 
composite membranes, in: A. Méndez-Vilas (Ed.), Current Microscopy Contributions to Advances in Science and Technology, Formatex, Badajoz, 2012.

[31] J. Hermia, Constant pressure blocking filtration laws - application to powerlaw nonnewtonian fluids, Trans IChemE 60 (1982) 183-187.

[32] R.W. Field, D. Wu, J.A. Howell, B.B. Gupta, Critical flux concept for microfiltration fouling, J. Membr. Sci. 100 (1995) 259-272.

[33] C. Jarusutthirak, S. Mattaraj, R. Jiraratananon, Influence of inorganic scalants and natural organic matter on nanofiltration membrane fouling, J. Membr. Sci. 287 (2007) 138145.

[34] C.C. Ho, L. Zydney, A combined pore blockage and cake filtration model for protein fouling during microfiltration, J. Colloid Interface Sci. 232 (2000) 389-399.

[35] E.J. de la Casa, A. Guadix, R. Ibáñez, F. Camacho, E.M. Guadix, A combined fouling model to describe the influence of the electrostatic environment on the cross-flow microfiltration of BSA, J. Membr. Sci. 318 (2008) 247-254.

[36] H. Carrère, F. Blaszkow, H. Roux de Balmann, Modelling the clarification of lactic acid fermentation broths by cross-flow microfiltration, J. Membr. Sci. 186 (2001) 219-230. [37] S. Ohnishi, M. Murata, M. Hato, Correlation between surface morphology and surface forces of protein A adsorbed on mica, Biophys. J. 74 (1998) 455-465.

[38] K. Blume, K. Dietrich, S. Lilienthal, W. Ternes, A.M. Drotleff, Exploring the relationship between protein secondary structures, temperature-dependent viscosities, and technological treatments in egg yolk and LDL by FTIR and rheology, Food Chem. 173 (2015) 584-593.

[39] S. Matheus, H.C. Mahler, W. Friess, A critical evaluation of T-m(FTIR) measurements of high-concentration $\operatorname{IgG}(1)$ antibody formulations as a formulation development tool, Pharmaceutical Res. 23 (2006) 1617-1627. 
[40] A. Pihlajamäki, P. Väisänen, M. Nyström, Characterization of clean and fouled polymeric ultrafiltration membranes by Fourier transform IR spectroscopy-attenuated total reflection, Colloids Surfaces A: Physicochem. Eng. Aspects 138 (1998) 323-333.

[41] K. Tsumoto, D. Ejima, A.M. Senczuk, Y. Kita, T. Arakawa, Effects of salts on protein-surface interactions: applications for column chromatography, J. Pharm. Sci. 96 (2007) 1677-1690.

[42] F. Zhang, F. Roosen-Runge, M.W.A. Skoda, R.M.J. Jacobs, M. Wolf, Ph. Callow, H. Frielinghaus, V. Pipich, S. Prévost, F. Schreiber, Hydration and interactions in protein solutions containing concentrated electrolytes studied by small-angle scattering, Phys. Chem. Chem. Phys. 14 (2012) 2483-2493. 
Table 1. Main properties of the membrane used.

\begin{tabular}{ll}
\hline Commercial code & UH030 \\
\hline Manufacturer & Microdyn Nadir \\
Type & Flat-sheet \\
Nominal MWCO $(\mathrm{kDa})$ & 30 \\
Active layer & PESH \\
Effective area $\left(\mathrm{cm}^{2}\right)$ & 35.25 \\
Water permeability at $25^{\circ} \mathrm{C}\left(\mathrm{L} / \mathrm{m}^{2} \cdot \mathrm{h} \cdot\right.$ bar $)$ & 106.00 \\
Maximum operating temperature $\left({ }^{\circ} \mathrm{C}\right)$ & 95 \\
pH range & $0-14$ \\
\hline
\end{tabular}

Table 2. Particle size measurements of pectinase solutions by DLS at various concentration and temperature.

\begin{tabular}{cccccc}
\hline $\begin{array}{c}\text { Temperature } \\
\left({ }^{\circ} \mathrm{C}\right)\end{array}$ & $\begin{array}{c}\text { Protein } \\
\text { concentration } \\
(\mathrm{g} / \mathrm{l})\end{array}$ & $\begin{array}{c}\text { Particle size } \\
\text { distribution } 1 \\
(\mathrm{~nm})\end{array}$ & $\begin{array}{c}\mathrm{PDI}_{1} \\
(\%)\end{array}$ & $\begin{array}{c}\text { Particle } \\
\text { distribution } 2 \\
(\mathrm{~nm})\end{array}$ & $\begin{array}{c}\mathrm{PDI}_{2} \\
(\%)\end{array}$ \\
\hline \multirow{2}{*}{$25^{\circ} \mathrm{C}$} & 15 & $15 \pm 4$ & 27 & $410 \pm 221$ & 54 \\
& 7 & $6 \pm 1$ & 17 & $91 \pm 38$ & 42 \\
$50{ }^{\circ} \mathrm{C}$ & 2 & $6 \pm 0.6$ & 10 & $61 \pm 18$ & 29 \\
& 15 & $12 \pm 3$ & 25 & $288 \pm 105$ & 36 \\
& 7 & $6 \pm 1$ & 17 & $17 \pm 4$ & 23 \\
\hline
\end{tabular}

PDI: polidispersity index percentage $=$ standard deviation $/$ intensity weighted $\mathrm{Z}$ average

Table 3. Values of model parameters for the best fitting models.

\begin{tabular}{ccccccc}
\hline \multirow{2}{*}{$\begin{array}{c}\text { Protein concentration } \\
(\mathrm{g} / \mathrm{L})\end{array}$} & \multicolumn{3}{c}{ Resistance-in-series model } & \multicolumn{3}{c}{ Combined model } \\
\cline { 2 - 7 } & $\mathrm{R}^{\prime}{ }_{\mathrm{ad}}\left(\mathrm{m}^{-1}\right)$ & $\mathrm{b}\left(\mathrm{s}^{-1}\right)$ & $\mathrm{R}_{\mathrm{c}}\left(\mathrm{m}^{-1}\right)$ & $\mathrm{K}_{\mathrm{c}}\left(\mathrm{s}^{-1}\right)$ & $\mathrm{K}_{\mathrm{cf}}\left(\mathrm{s} / \mathrm{m}^{2}\right)$ & $\alpha$ \\
\hline 2 & $1.542 \cdot 10^{13}$ & $3.637 \cdot 10^{-4}$ & $8.181 \cdot 10^{12}$ & 32.555 & $2.518 \cdot 10^{6}$ & 0.937 \\
7.5 & $8.865 \cdot 10^{13}$ & $3.388 \cdot 10^{-5}$ & $1.724 \cdot 10^{13}$ & 36.101 & $1.875 \cdot 10^{7}$ & 0.967 \\
15 & $3.717 \cdot 10^{17}$ & $8.994 \cdot 10^{-9}$ & $4.511 \cdot 10^{13}$ & 60.854 & $5.075 \cdot 10^{9}$ & 1.000 \\
\hline
\end{tabular}

Table 4. Residual protein concentration after cleaning procedure and water permeability recovery.

\begin{tabular}{|c|c|c|c|}
\hline Membrane & $\begin{array}{l}\text { Protein concentration during } \\
\text { fouling }(\mathrm{g} / \mathrm{L})\end{array}$ & $\begin{array}{l}\text { Residual protein } \\
\text { concentration } \\
\left(\mu \mathrm{g} / \mathrm{cm}^{2}\right)\end{array}$ & $\begin{array}{c}\text { Cleaning } \\
\text { efficiency }(\%)\end{array}$ \\
\hline \multirow{3}{*}{$\begin{array}{l}\text { Cleaned with } \\
\qquad \mathrm{NaCl}\end{array}$} & 2 & $4 \pm 1$ & $100 \pm 3$ \\
\hline & 7.5 & $9 \pm 1$ & $100 \pm 3$ \\
\hline & 15 & $14 \pm 2$ & $100 \pm 1$ \\
\hline $\begin{array}{l}\text { Cleaned with } \\
\mathrm{Na}_{2} \mathrm{SO}_{4}\end{array}$ & 15 & $25 \pm 1$ & $97 \pm 1$ \\
\hline
\end{tabular}




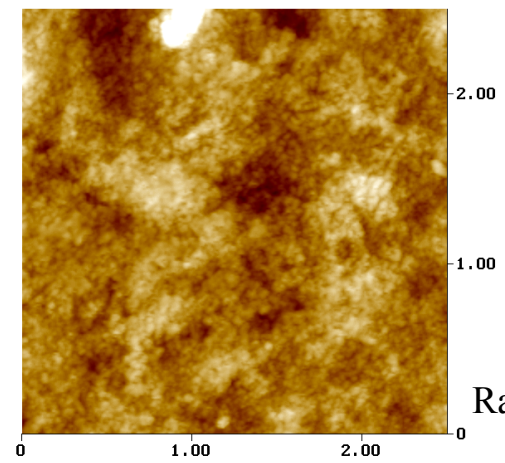

$\mathrm{Ra}=5 \pm 2 \mathrm{~nm}$

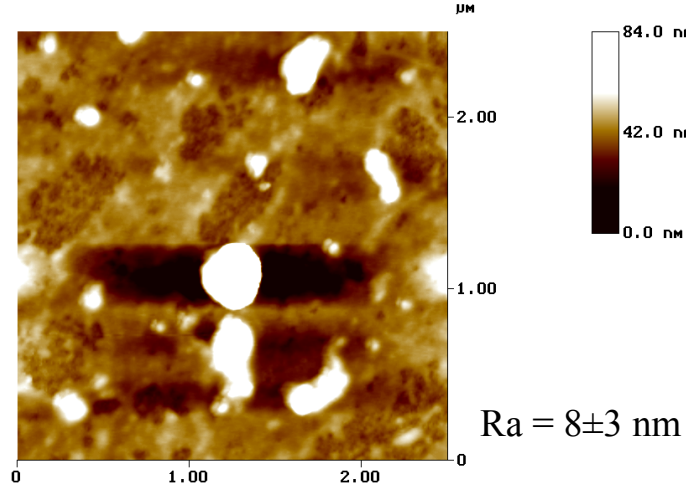

(c)

(a)
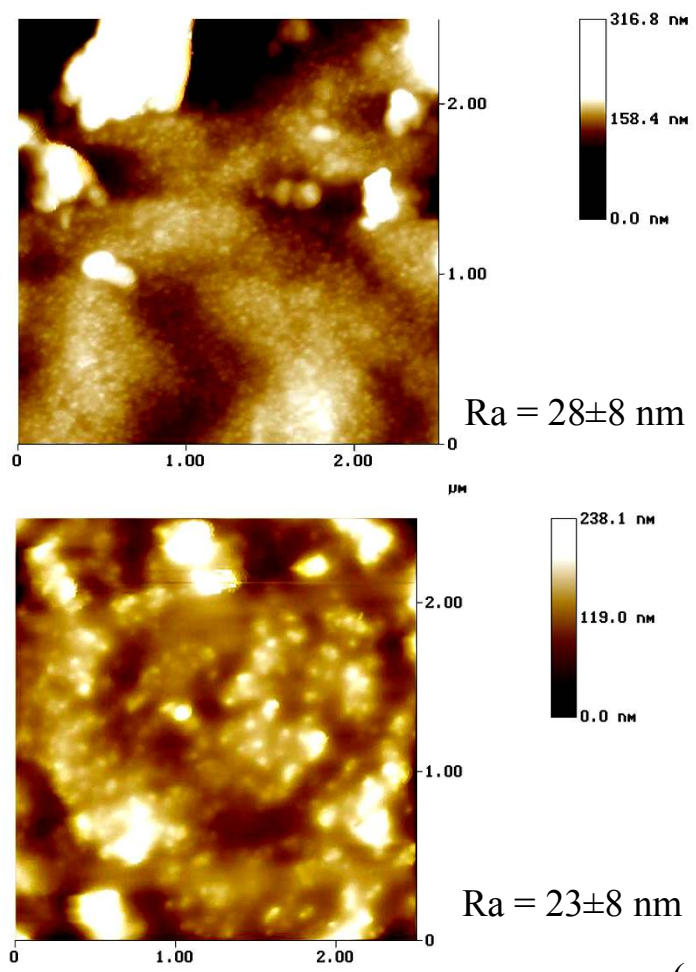

(d)

Fig. 1. AFM images of new membrane (a) and membranes fouled with enzymatic solutions at $2 \mathrm{~g} / \mathrm{L}$ (b), $7.5 \mathrm{~g} / \mathrm{L}$ (c) and $15 \mathrm{~g} / \mathrm{L}(\mathrm{d})$. 

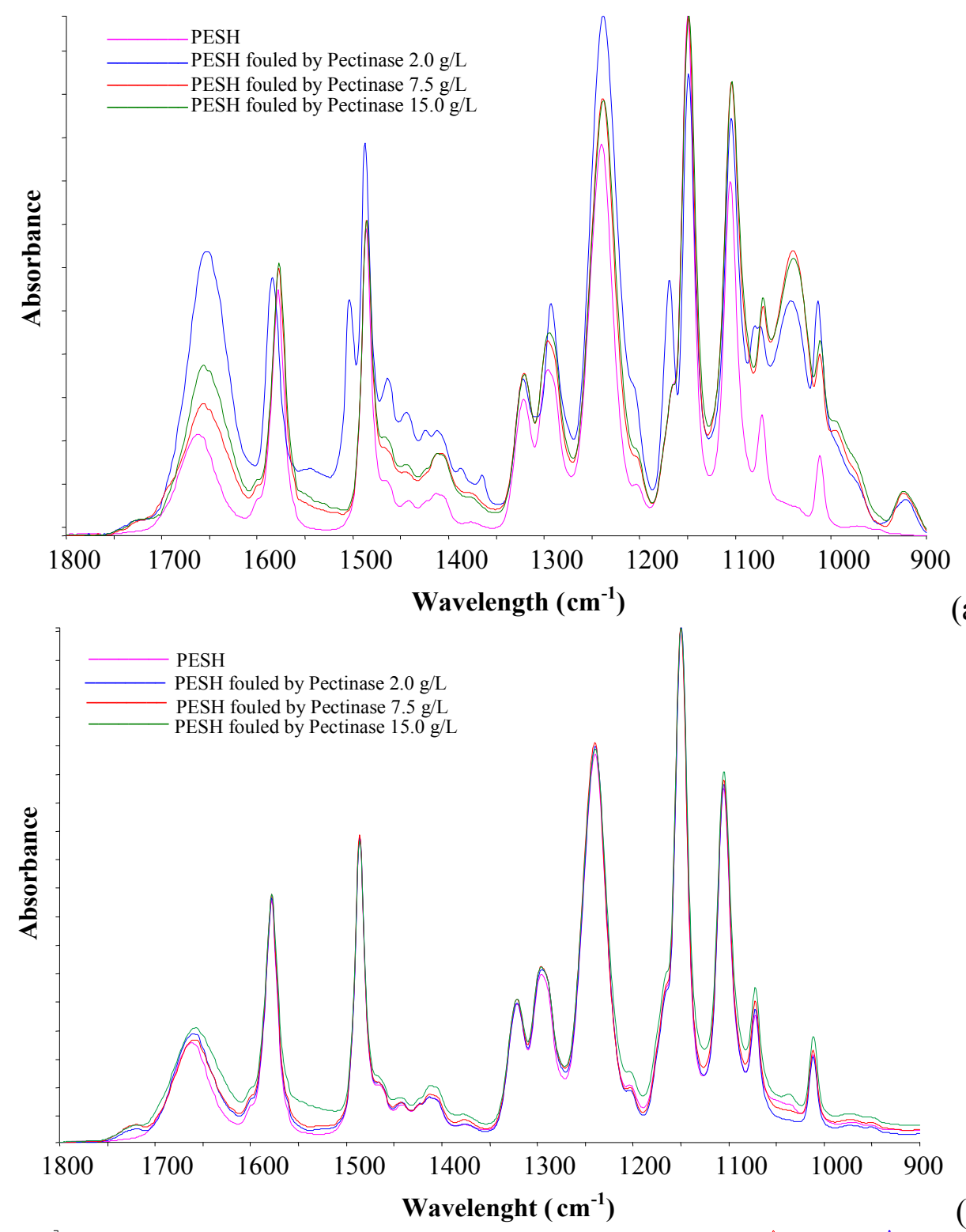

(a)

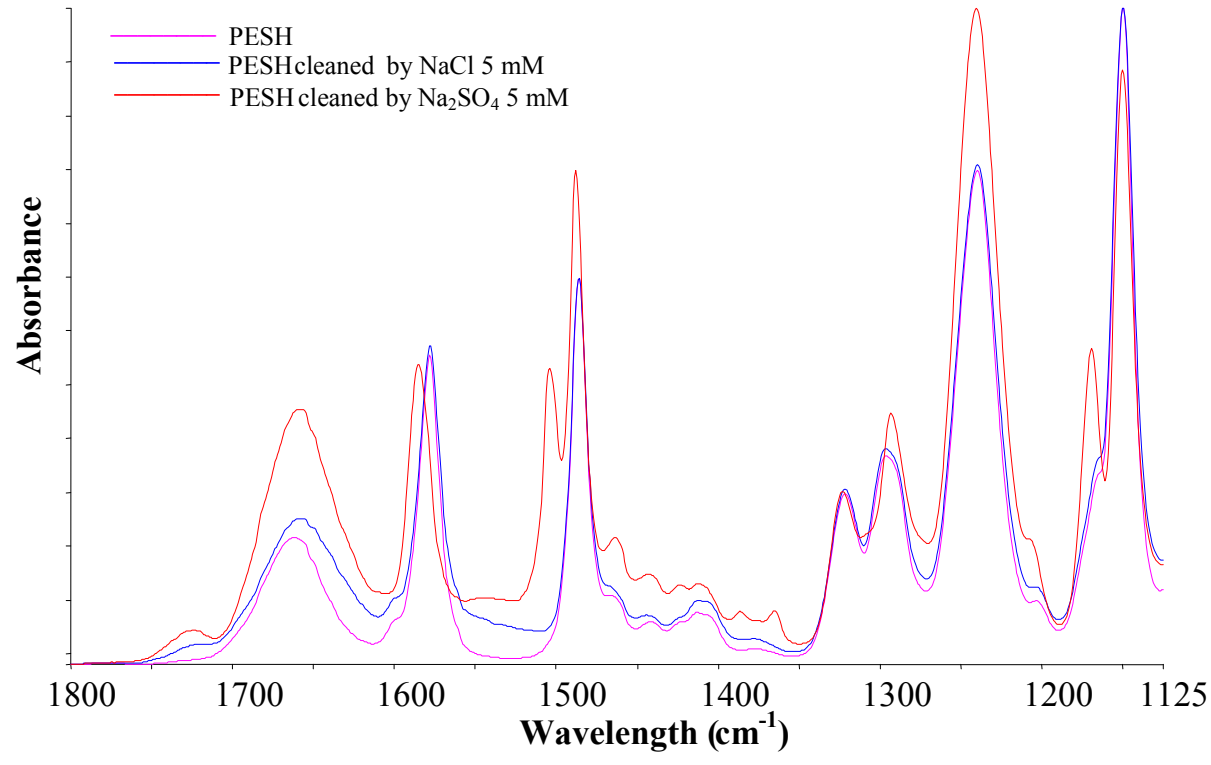

(b)

(c)

Fig. 2. ATR-FTIR spectra of new membrane and (a) membranes fouled with enzymatic solutions at 2, 7.5 and $15 \mathrm{~g} / \mathrm{L}$; (b) membranes cleaned with $\mathrm{NaCl}$ (enzymatic solution 
concentration during fouling: 2, 7.5 and $15 \mathrm{~g} / \mathrm{L}$ ); (c) membranes cleaned with $\mathrm{NaCl}$ and $\mathrm{Na}_{2} \mathrm{SO}_{4}$ (enzymatic solution concentration during fouling: $15 \mathrm{~g} / \mathrm{L}$ ). 


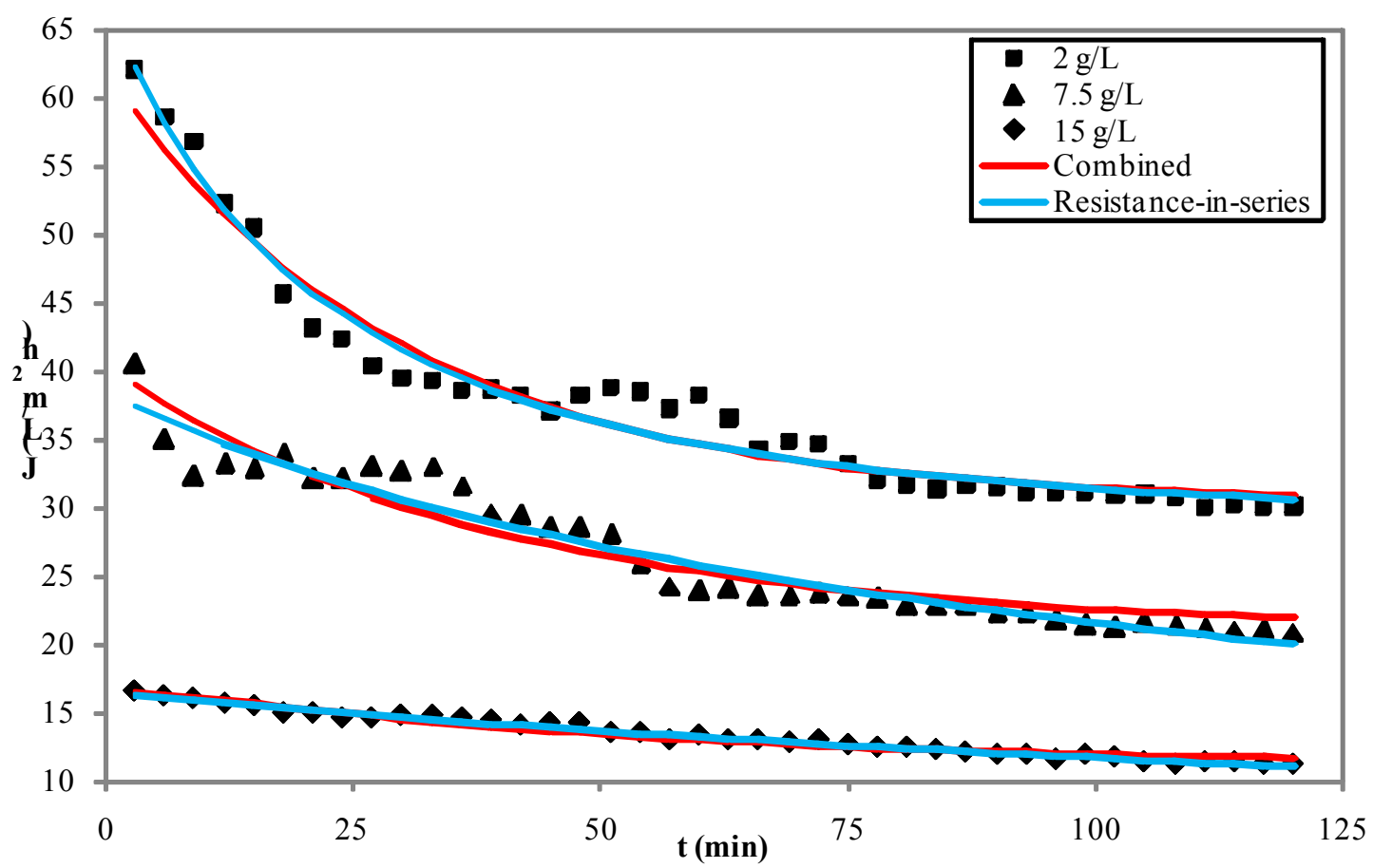

Fig. 3. Permeate flux predictions for the best fitting models using enzymatic solutions (lines: estimated results; symbols: experimental data). 